Dinamika Sosial Budaya, Vol 19, No. 2, Desember 2017, pp 286-299

p-ISSN: $1410-9859 \&$ e-ISSN: 2580-8524

http://journals.usm.ac.id/index.php/jdsb

\title{
KAJIAN POLA PEMBIAYAAN USAHA PADA UMKM EKONOMI \\ KREATIF KOTA SEMARANG
}

\author{
Indarto \\ Program Magister Manajemen Pasca Sarjana Universitas Semarang, \\ indarto@usm.ac.id \\ Djoko Santoso \\ Program Magister Manajemen Pasca Sarjana Universitas Semarang, \\ djokosantoso@usm.ac.id

\section{Aprih Santoso} \\ Program Magister Manajemen Pasca Sarjana Universitas Semarang, \\ aprihsantoso@usm.ac.id
}

\begin{abstract}
Abstrak
UMKM adalah pelaku penting dalam industri ekonomi kreatif di Indonesia. Potensi UMKM dalam ekonomi kreatif di Indonesia sangat besar mengingat Indonesia sangat kaya dengan keragaman kesenian dan kebudayaan.Demikian juga dengan potensi UMKM ekonomi kreatif di Kota Semarang. Harus diakui bahwa perkembangan UMKM ekonomi kreatif masih relatif tertinggal dari dibandingkan dengan perkembangan UMKM ekonomi kreatif di kota-kota seperti; Bandung, Yogyakarta malang dan lain-lain. Penelitian ini bermaksud mengkaji apakah kinerja usaha UMKM ekonomi kreatif di Kota Semarang yang masih tertinggal dibanding kota-kota lain berkaitan dengan pola pembiayaan UMKM itu sendiri. Penelitian ini menggunakan metode kualitatif dengan pendekatan fenomenologis. Informan dalam penelitian adalah 12 pelaku UMKM Ekonomi Kreatif di Kota Semarang. Pengumpulan data dengan metode wawancara, observasi dan dokumentasi. Hasil penelitian menunjukkan bahwa dengan pendekatan fenomenologis ditemukan 2 pola pembiayaan usaha yang diterapkan oleh pelaku UMKM Ekonomi Kreatif yaitu pola pembiayaan usaha yang cenderung menghindari risiko dan pola pembiayaan pembiayaan yang berani mengambil risiko.Pola pembiayaan usaha yang berani mengambil risiko menunjukkan perkembangan usaha yang lebih pesat daripada pola pembiayaan usaha yang menghindari risiko.

Keywords: UMKM ekonomi kreatif, pola pembiayaan usaha, kinerja usaha, risiko,
\end{abstract}

\begin{abstract}
Micro, Small dan Medium Enterprises(MSMEs ) is an important player in the creative economy industry in Indonesia. The potential of MSMEs in the creative economy in Indonesia is very big considering Indonesia is very rich with the diversity of art and culture. Likewise with the potential of SMEs creative economy in the city of Semarang. It must be admitted that the development of MSMEs in creative economy is still relatively lagging behind compared to the development of MSMEs creative economy in cities such as; Bandung, Yogyakarta unfortunate and others. This study intends to examine whether the performance of MSMEs in the creative economy of Semarang City is still behind compared to other cities related to the pattern of financing UMKM itself. This research used qualitative method with phenomenological approach. Informants in the study are 12 perpetrators of Creative Economy MSMEs in Semarang City. Data collection by interview method, observation and documentation. The results showed that with phenomenological approach found 2 business financing patterns applied by the perpetrators of MSMEs Creative Economy is the pattern of business financing that tends to avoid risks and financing patterns of financing that dare to take risiko. Business financing pattern that dare to take risks show the development of business more rapidly than the pattern of business financing that avoids risk.

Keywords: MSMEs, creative economy, business financing pattern, business performance, risk
\end{abstract}


Dinamika Sosial Budaya, Vol 19, No. 2, Desember 2017, pp 286-299

p-ISSN: 1410-9859\& e-ISSN: 2580-8524

http://journals.usm.ac.id/index.php/jdsb

\section{PENDAHULUAN}

Pengembangan ekonomi kreatif agar dapat menjadi tulang punggung perekonomian nasional ke depan telah menjadi komitment dalam Rencana Pembangunan Jangka Menengah Nasional (RPJMN) Tahun 2015 - 2019, sebagaimana tercantum pada Nawa Cita butir ke enam "Meningkatkan produktivitas rakyat dan daya saing di pasar internasional sehingga bangsa Indonesia bisa maju dan bangkit bersama-sama bangsa Asia lainnya". Hal ini merupakan dukungan kebijakan strategis dan diversifikasi sumber-sumber pertumbuhan ekonomi nasional, memperluas peluang dan iklim kondusif bagi pengembangan ekonomi kreatif. Pengembangan ekonomi kreatif adalah dalam rangka mengatasi permasalahan dan tantangan pembangunan nasional dan mengurangi ketergantungan ekonomi nasional pada sektor ektrasi sumberdaya alam (bahan tambang, mineral dan perkebunan), masalah kemiskinan, pengangguran terbuka, termasuk kelompok usia muda dan terdidik di perkotaan.

Perkembangan ekonomi baru yang berbasis Iptek dan kreativitas telah dimulai sejak tahun 1990an dengan sebutan ekonomi kreatif yang digerakkan oleh sektor industri yang disebut industri kreatif. Ekonomi kreatif merupakan upaya pembangunan ekonomi secara berkelanjutan melalui kreativitas, inovasi dengan menumbuhkan iklim usaha, daya saing dan berbasis Iptek termasuk warisan budaya (Departemen Perdagangan, 1998). Adapun pelaku utama ekonomi kreatif adalah aktor-aktor pelaku ekonomi kreatif terdiri dari empat (4) kelompok, yaitu : (1) pemerintah/pemerintah daerah,

akademisi/cendekiawan, (3) "komunitas kreatif", dan (4) pelaku bisnis. Keempat pelaku ekonomi kreatif disebut quadrouple-helix (Bekraf, 2016).
Potensi dan sumbangan ekonomi kreatif dalam perekonomian nasional menunjukkan peningkatan yang cukup baik dari tahun ke tahun. Berdasarkan data Badan Ekonomi Kreatif (Bekraf) tahun 2010 - 2014 rata-rata sumbangan ekonomi kreatif mencapai sebesar $7,1 \%$ dari produk domestik bruto (PDB) Indonesia. Data BPS (tahun 2014) nilai tambah yang dihasilkan dari ekonomi kreatif lebih kurang sebesar Rp. 716,7 trilyun dengan rata-rata pertumbuhan mencapai $5,81 \%$. Jumlah tenaga kerja yang terserap lebih kurang 12 juta orang dalam industri kreatif (Bekraf, 2016). Dari sebanyak 16 subsektor ekonomi kreatif terdapat lima (5) subsektor yang memberikan kontribusi terbesar yaitu pertama adalah subsektor kuliner (sebesar 32,4\%), kedua adalah mode/fashoin (sebesar $28,71 \%$ ), ketiga adalah seni kriya (sebesar 14,11\%), keempat adalah penerbitan (sebesar 7,98\%) dan kelima adalah desain produk $(3,82 \%)$.

Perkembangan perekonomian nasional erat kaitannya dengan ekonomi kreatif, terutama didukung faktor-faktor sebagai berikut : 1) Meningkatnya jumlah penduduk kelompok usia produktif (terutama umur 15 - 54 tahun) dan pada tahun 2030 Indonesia akan mengalami "bonus demografi” dengan jumlah kelompok usia produktif akan mencapai sebanyak $60 \%$ dan sebesar $27 \%$ diantaranya adalah penduduk muda (rentang usia 16 - 30 tahun) yang berpotensi menjadi kelompok usia kreatif (creative class); 2) Potensi kekayaan alam dan budaya. Indonesia memiliki warisan budaya yang diakui dunia (World Cultural Heritage), potensi budaya yang beragam (terdapat 250 suku bangsa) serta kekayaan dan keindahan alam yang menjadi bahan baku ekonomi kreatif; 3) Meningkatnya jumlah kelompok menengah. Pada tahun 2030 diperkirakan sebanyak 135 juta orang kelompok menengah akan memiliki pendapatan bersih (net income) diatas US \$3.600/ kapita 
Dinamika Sosial Budaya, Vol 19, No. 2, Desember 2017, pp 286-299

p-ISSN: 1410-9859\& e-ISSN: 2580-8524

http://journals.usm.ac.id/index.php/jdsb

sebagai "konsumen ekonomi kreatif"; 4) Perkembangan gaya hidup digital. Meningkatnya akses teknologi informasi dan komunikasi sudah menjangkau lebih dari 90\% dari populasi Indonesia; Meningkatnya permintaan produk-produk kreatif, peningkatan di pasar global terutama produk berbasis media dan UCT (content industry) (Hamdan, 2016).

Provinsi Jawa Tengah merupakan salah satu dari pusat pengembangan ekonomi kreatif nasional, potensi sumberdaya manusia sebagai insan kreatif, pelaku usaha dan lingkungan strategis bagi pengembangan ekonomi kreatif terutama berbasis budaya dan kearifan lokal menunjukkan pertumbuhan yang menggembirakan. Dari 16 subsektor ekonomi kreatif tersebut, di Jawa Tengah terdapat enam (6) subsektor potensial dan perkembangannya cukup baik, yaitu : kuliner, seni kriya, fashion, film dan video dan aplikasi perangkat lunak dan games serta seni musik/pertunjukkan. Berdasarkan hasil kajian cepat dari Badan Ekonomi Kreatif (2017) pada diskusi kelompok terfokus (FGD) di Semarang 30 Maret 2017, terdapat tiga (3) subsektor yang menjadi prioritas untuk dikembangkan meliputi : subsektor kuliner, seni kriya dan fashion/mode (SM, 31 Maret 2017).

Namun demikian, perkembangan ekonomi kreatif pada umumnya menghadapi masalah pemanfaatan Iptek yang masih rendah, rendahnya daya saing ekonomi kreatif dan peran pemangku kepentingan (stakeholders), tingkat inovasi dari "komunitas kreatif" dan masih kurangnya promosi serta pemasaran pada umumnya. Berdasarkan kajian dari Menko Bidang Perekonomian/Deputi Bidang Koordinasi Ekonomi Kreatif, Kewirausahaan dan Daya Saing Koperasi dan UMKM (2016), pengembangan ekonomi menghadapi tantangan, terkait dengan aspek : (1) kemampuan sumberdaya manusia dan komunitas kreatif, (2) kelembagaan, (3) teknologi dan informatika, (4) pemasaran dan (5) sumberdaya pendukung, masing-masing dapat dikemukakan sebagai berikut : 1) Relatif rendahnya kualitas sumberdaya manusia (SDM), baik pendidikan tenaga kerja dan pelaku usaha, terutama pelaku usaha kuliner, kerajinan/kriya, mode dan fahion, permainan interaktif; 2) Belum berkembangnya kelembagaan "komunitas kreatif", terutama pelaku pada subsektor : arsitektur, film dan video, termasuk animasi, seni pertunjukkan dan televisi dan radio; 3) Sumberdaya pendukung masih relatif lemah, terutama pada subsektor usaha arsitektur, fotografi, seni musik dan senirupa; 4) Belum memadainya infrastruktur dan teknologi bagi pengembangan ekonomi kreatif, terutama untuk pengembangan subsektor design industri, permainan interaktif dan piranti lunak, periklanan, dan pengembangan teknologi informatika; 5) belum optimalnya fasilitasi pemasaran, terutama subsektor film dan video, kuliner dan musik agar bersaing di dunia internasional seperti K-Pop (Korea Selatan) (Menko Bidang Perekonomian dalam Hamdan, 2016).

Pemerintah Kota Semarang saat ini juga giat mengembangkan potensi ekonomi kreatif, dengan alasan bahwa pengembangan ekonomi kreatif terkait erat dengan citra dan identitas bangsa dan daerah, terutama aspek pariwisata, ikon nasional, membangun dan melestarikan budaya serta warisan dan nilai-nilai lokal (budaya lokal).

UMKM Ekonomi Kreatif Kota Semarang memiliki potensi yang tinggi namun masih banyak menghadapi kelemahan. Berdasarkan hasil penelitian Artiningsih dkk (2010), diketahui bahwa secara umum industri ekonomi kreatif di Kota Semarang tergolong lemah terkait dalam upaya penciptaan nilai tambah. Semakin panjang mata rantai yang dilakukan dalam suatu industri, akan 
Dinamika Sosial Budaya, Vol 19, No. 2, Desember 2017, pp 286-299

p-ISSN: 1410-9859\& e-ISSN: 2580-8524

http://journals.usm.ac.id/index.php/jdsb

semakin berkembang industri tersebut. Sebagian besar industri kreatif di Kota Semarang belum mampu menjadi ikon yang mencerminkan Kota Semarang, sementara sebenarnya banyak potensi yang dapat dikembangkan. Ditinjau dari segi pendistribusian produk, hanya sebagian kecil industri yang telah berhasil menembus pasar internasional, namun industri-industri tersebut belum cukup berkontribusi terhadap pendapatan Kota Semarang. Beberapa masalah yang dihadapi UMKM Ekonomi Kreatif Kota Semarang diantaranya adalah masih rendahnya pengembangan desain produk, permasalahan tenaga kerja yang kurang, produk yang belum memiliki HAKI, peralatan yang masih menggunakan peralatan tradisional, dan masalah klasik yang sering dihadapi seperti permasalahan modal dan sulitnya pemasaran. Keterbatasan modal menjadi masalah klasik bagi pelaku umkm termasuk umkm ekonomi kreatif Kota Semarang. Struktur modal UMKM lebih mengutamakan pada pembiayaan sendiri. Kurangnya akses terhadap modal dari perbankan dan kurang beraninya UMKM untuk mengambil risiko menyebabkan sebagian besar lebih mengandalkan modal sendiri.

Penelitian ini bermaksud mengkaji pola pembiayaan pada UMKM Ekonomi Kreatif dan kaitan pembiayaan modal tersebut dengan kinerja UMKM Ekonomi Kreatif itu sendiri. Kajian ini perlu dilakukan untuk dapat melihat fenomena pola pembiayaan modal yang ada pada umkm ekonomi kreatif. Masalah pembiayaan modal menjadi masalah klasik UMKM dalam pengembangan usahanya. UMKM Ekonomi kreatif diharapkan mampu mengembangkan kinerja usahanya sehingga mampu memberikan kontribusi yang semakin besar terhadap perekonomian lokal maupun perekonomian nasional. Berkaitan dengan permasalahan permodalan umkm tersebut maka tujuan penelitian ini adalah mengkaji pola pembiayaan yang diterapkan oleh pelaku
UMKM Ekonomi Kreatif . Penelitian ini diharapkan memperoleh informasi yang penting mengenai pola pembiayaan modal pada UMKM Ekonomi Kreatif dan kaitannya dengan kinerja UMKM itu sendiri. Hasil kajian ini nantinya dapat menjadi dasar dalam penyusunan strategi pengembangan UMKM Ekonomi Kreatif khususnya di Kota Semarang dalam hal kebijakan akses modal.

\section{METODE}

Pendekatan yang digunakan dalam penelitian ini adalah pendekatan kualitatif. Metodologi kualitatif mampu menggali pemahaman yang mendalam mengenai organisasi atau peristiwa khusus daripada mendeskripsikan bagian permukaan dari sampel besar dari sebuah populasi. Hal ini sesuai dengan penelitian yang akan dilakukan dalam rangka memahami kondisi UMKM berbasis ekonomi kreatif di Kota Semarang secara mendalam dengan latar alamiah tanpa adanya intervensi atau manipulasi baik dari peneliti sendiri maupun dari pihak lain.

Penelitian ini menggunakan model fenomenologi dalam pendekatan kualitatif dimana model ini berusaha memahami arti dari suatu peristiwa yang terjadi karena adanya interaksi dari pihak-pihak yang terlibat, dimana pihak-pihak yang terlibat tersebut memiliki pemahaman atau interpretasi masing-masing (intersubjektif) terhadap setiap peristiwa yang akan menentukan tindakannya. Informan dalam penelitian ini yaitu pelaku UMKM kreatif di Kota Semarang, dinas terkait (dinas Koperasi dan UMKM Semarang), serta pengamat UMKM Ekonomi Kreatif . Informan diambil berdasarkan strategi sampling bola salju (snowball sampling). Hal ini dikarenakan fenomena yang diteliti dapat berkembang menjadi lebih dalam dan lebih luas dari yang ditentukan sebelumnya sehingga disesuaikan dengan kebutuhan data yang telah 
Dinamika Sosial Budaya, Vol 19, No. 2, Desember 2017, pp 286-299

p-ISSN: 1410-9859\& e-ISSN: 2580-8524

http://journals.usm.ac.id/index.php/jdsb

diperoleh. Strategi ini digunakan agar diperoleh data yang akurat dan mendalam mengenai kondisi serta permasalahan UMKM. Penelitian ini dilakukan di beberapa kecamatan di Kota Semarang yaitu Semarang Timur, Semarang Barat, Semarang Selatan, Semarang Utara, Semarang Tengah, Pedurungan, Tembalang, Banyumanik, Gajahmungkur, dan Genuk.

Jenis data yang digunakan dalam penelitian ini adalah data primer dan data sekunder. Data primer yang dibutuhkan dalam penelitian ini diperoleh melalui hasil wawancara mendalam dengan pelaku UMKM Ekonomi kreatif di Kota Semarang, dinas terkait, dan berbagai pihak yang telah dipilih menjadi informan. Data sekunder yang digunakan dalam penelitian ini diperoleh dengan cara dokumentasi dari literatur, publikasi ilmiah yang berkaitan dengan UMKM dan pola pembiayaan serta dari instansi terkait seperti dinas Koperasi dan UMKM, dinas Perindustrian dan Perdagangan Kota Semarang, serta Badan Pusat Statistik (BPS).

Proses analisis data dalam penelitian kualitatif dimulai dan dilakukan sejak awal penelitian hingga penelitian selesai. Hal ini berarti, setiap peneliti melakukan proses pengambilan data, peneliti langsung melakukan analisis dari data tersebut seperti pemilahan tema dan kategorisasinya. Dalam penelitian ini, peneliti menggunakan model analisis data interaktif menurut Miles dan Huberman. Model analisis data ini memiliki 4 tahapan, yaitu tahap pertama pengumpulan data, tahap kedua reduksi data, tahap ketiga display data, dan tahap keempat penarikan kesimpulan serta verifikasi data.

\section{HASIL DAN PEMBAHASAN}

\section{Analisis Informasi dari UMKM Ekonomi Kreatif}

Informan dalam penelitian mengenai pola pembiayaan usaha UMKM Ekonomi Kreatif ini adalah para pengusaha yang memiliki usaha dalam produksi produk-produk kreatif seperti batik, handycraft, accesories dan lain-lain. Sebanyak 12 orang pelaku UMKM Ekonomi Kreatif yang tersebar di Kota Semarang menjadi informan dalam penelitian ini. Kedua belas infroman tersebut memenuhi syarat untuk diwawancara dan diobservasi. Syarat tersebut adalah; 1) lama usaha lebih dari 2 tahun sehingga sudah terlihat eksitensinya; 2) memiliki tenaga kerja minimal 2 ; 3) berproduksi secara kontinyu artinya berproduksi setiap hari meskipun jumlah produksi berdasarkan pesanan.

Tabel 1.Daftar Informan UMKM Ekonomi Kreatif

\begin{tabular}{|c|c|c|c|}
\hline $\mathrm{NO}$ & $\begin{array}{l}\text { NAMA UMKM } \\
\text { EKONOMI } \\
\text { KREATIF }\end{array}$ & PEMILIK & PRODUK \\
\hline 1 & $\begin{array}{l}\text { KINGDOM } \\
\text { LABEL }\end{array}$ & Natalia & $\begin{array}{l}\text { Stiker, label, } \\
\text { stempel }\end{array}$ \\
\hline 2 & $\begin{array}{l}\text { BATIK } \\
\text { SUMBER } \\
\text { REJEKI }\end{array}$ & Sri Winarti & Batik tulis \\
\hline 3 & $\begin{array}{l}\text { CAND's } \\
\text { COLLECTION }\end{array}$ & Y.Candrawati & $\begin{array}{l}\text { Jilbab, } \\
\text { accecories }\end{array}$ \\
\hline 4 & $\begin{array}{l}\text { TITA } \\
\text { COLLECTION }\end{array}$ & $\begin{array}{l}\text { Titik Ika } \\
\text { Purbyanti }\end{array}$ & Handycraft \\
\hline 5 & $\begin{array}{l}\text { IKENIA } \\
\text { HANDMADE }\end{array}$ & $\begin{array}{l}\text { Niken Ratih } \\
\text { Irawati }\end{array}$ & $\begin{array}{l}\text { Tas rajut, } \\
\text { bros }\end{array}$ \\
\hline 6 & LE ZUKI & Giffen & $\begin{array}{l}\text { Kursi } \\
\text { karakter }\end{array}$ \\
\hline 7 & $\begin{array}{l}\text { AZNAY } \\
\text { MACRAME }\end{array}$ & Iis Deviana & Accesories \\
\hline 8 & BATIK ARJUNA & Monica & $\begin{array}{lr}\text { Batik dan } \\
\text { Produk Batik } \\
\end{array}$ \\
\hline 9 & $\begin{array}{l}\text { META } \\
\text { COLLECTION }\end{array}$ & $\begin{array}{l}\text { Meta Nuzatu } \\
\text { Zaman }\end{array}$ & $\begin{array}{l}\text { Produk } \\
\text { kreatif } \\
\text { (bantal, } \\
\text { taplak, tas, } \\
\text { clutch dll) }\end{array}$ \\
\hline 10 & $\begin{array}{l}\text { SINTA } \\
\text { COLECTION }\end{array}$ & Sinta & $\begin{array}{l}\text { Kerajinan } \\
\text { sulam pita }\end{array}$ \\
\hline 11 & DIAZ RAJUT & $\begin{array}{l}\text { Punkie } \\
\text { Widiastuti }\end{array}$ & $\begin{array}{l}\text { Sepatu, tas, } \\
\text { clutch }\end{array}$ \\
\hline 12 & $\begin{array}{l}\text { BATIK } \\
\text { SIWARAK } \\
\text { KANDRI }\end{array}$ & Ainan Hayati & Batik tulis \\
\hline
\end{tabular}

Sumber : data primer, 2017

Peneliti secara langsung mewawancarai secara mendalam setiap informan dan melakukan observasi di tempat usaha para informan sehingga 
Dinamika Sosial Budaya, Vol 19, No. 2, Desember 2017, pp 286-299

p-ISSN: 1410-9859\& e-ISSN: 2580-8524

http://journals.usm.ac.id/index.php/jdsb

diperoleh informasi yang akurat dan lengkap untuk bahan analisis dalam penelitian ini. Sebagian pelaku UMKM Ekonomi Kreatif yang menjadi adalah kaum perempuan. Fenomena ini sangat menarik. Kaum perempuan sangat dekat dengan ketrampilan dan keindahan. Para pelaku UMKM ekonomi kreatif yang rata-rata perempuan tersebut lahirlah produkproduk reatif yang bernilai tambah tinggi.Para informan rata-rata telah menjalani usaha dari $2-15$ tahun. Dilihat lama usaha para informan UMKM Ekonomi Kreatif ini telah menjalani usaha nya paling tidak 2 tahun dan paling lama 15 tahun. Hal tersebut menunjukkan bahwa para informan telah memiliki pengalaman yang cukup dalam menjalankan usahanya dalam bidang ekonomi kreatif, bahkan ada yang bertahan sampai 15 tahun. Lama usaha sampai dengan 10 tahun ke atas membuktikan bahwa para pelaku UMKM Ekonomi Kreatif tersebut memiliki daya saing yang tinggi sehingga mampu bertahan dalam persaingan yang ketat. UMKM Ekonomi kreatif membutuhkan tenaga kerja yang benar-benar terampil , menguasai benar bidangnya dan memiliki kreativitas yang tinggi. Karena tuntutan yang tinggi tersebut maka tidak banyak tenaga kerja yang mampu bertahan di bidang ekonomi kreatif. Rata-rata UMKM Ekonomi Kreatif memiliki tenaga kerja anatar 2 - 15 orang.

Berdasarkan jangkauan pemasaran, UMKM

Ekonomi Kreatif telah memiliki jangkauan pemasaran yang cukup bagus, tidak hanya di sekitar Semarang, tetapi paling tidak sudah menjangkau beberapa wilayah di Indonesia, bahkan ada yang sudah bisa ekspor. Profil pemasaran UMKM Ekonomi Kreatif tersebut menunjukkan bahwa produk-produk ekonomi kreatif dari UMKM Ekonomi kreatif di Kota Semarang cukup memiliki daya saing yang tinggi. Sebagian besar produksi UMKM Ekonomi Kreatif tergantung pada pesanan. Meskipun tergantung pada pesanan, tetapi semua
UMKM Ekonomi kreatif yang menjadi informan dalam penelitian ini setiap hari berproduksi . Ketika UMKM Ekonomi Kreatif mampu menghasilkan produk yang menarik dan kreatif, maka pesanan akan terus mengalir dan UMKM ekonomi kreatif akan terus eksis. Berkaitan dengan aspek produksi UMKM Ekonomi Kreatif pernyataan menarik yang disampaikan informan adalah;

“ Kami pelaku ekonomi kreatif ini harus proaktif mempromosikan produk-produk kami agar kami terus mendapat pesanan. Berapa jumlah produksi kami setiap harinya tergantung dari pesnan. Maka pendapatan kita juga sangat bergantung dengan ramai tidaknya pesanan atas produk-produk kami." (Diaz Collection).

Omzet UMKM Ekonomi Kreatif cukup menarik untuk disimak. Rata-rata UMKM Ekonomi Kreatif mampu menjual produknya dan memperoleh hasil penjualan antara Rp 1.000 .000 per bulan sampai dengan Rp 120.000.000 per bulan. Margin profit produk ekonomi kreatif sangat menarik, yaitu antara $25 \%-75 \%$. Margin profit yang tinggi pada usaha ekonomi kreatif ini disebabkan nilai tambah yang tinggi papa produk-produk ekonomi kreatif. Produk ekonomi kreatif adalah produk dari daya kreativitas yang tinggi sehingga konsumen tidak akan keberatan dengan harga yang ditetapkan oleh produsen karena dapat menikmati keindahan, keunikan dan kekhasan produk-produk ekonomi kreatif. Apalagi biasanya produk ekonomi kreatif dibuat secara handmade, sehingga memberi kesan ekslusif dan privacy pada pemakainya.Mengenai margin profit, rata-rata pelaku ekonomi kreatif menyatakan bahwa produk ekonomi kreatif merupakan hasil dari proses kreatif, jadi tidak sekedar dihitung dari biaya produksi saja, tetapi juga dari proses kreatifnya. Berikut pernyataanpernyataan yang mengegaskan hal tersebut ;

Meta Collection

" kita berani mengambil margin profit yang tinggi karena produk ekonomi kreatif selalu handmade, 
Dinamika Sosial Budaya, Vol 19, No. 2, Desember 2017, pp 286-299

p-ISSN: 1410-9859\& e-ISSN: 2580-8524

http://journals.usm.ac.id/index.php/jdsb

eksklusif dan unik. Yang dihargai lebih mahal kan ide dan kreatifitas kita”

Tita Collection

"Memang seperti handycraft itu kan membuatnya tidak mudah, harus telaten, jadi ya wajar kalau kami mengambil keuntungan yang layak”.

Batik Arjuna

" Kelebihan membuat produk ekonomi kreatif itu, keuntungannya lumayan, tidak ada risiko busuk, basi dan lain-lain, di jual kapan pun tidak kadaluwarsa. Kalau barangnya benar-benar unik, konsumen seneng, harga tidak menjadi masalah bagi mereka. Jadi keuntungan membuat produk kreatif bisa lebih tinggi dari barang-barang biasa . Bedanya , produk ekonomi kreatif belum tentu laku setiap hari."

Tabel 2. Pola Pembiayaan Modal Awal UMKM Ekonomi

\begin{tabular}{|c|c|c|}
\hline \multicolumn{2}{|l|}{ Kreatif } & \\
\hline $\begin{array}{l}\text { UMKM } \\
\text { EKONOMI } \\
\text { KREATIF }\end{array}$ & $\begin{array}{l}\text { MODAL } \\
\text { AWAL }\end{array}$ & $\begin{array}{l}\text { SUMBER MODAL } \\
\text { AWAL }\end{array}$ \\
\hline $\begin{array}{l}\text { KINGDOM } \\
\text { LABEL }\end{array}$ & 20.000 .000 & $\begin{array}{lr}\begin{array}{l}\text { Modal } \\
\text { ditambah }\end{array} & \text { sendiri } \\
\text { bank } & \\
\end{array}$ \\
\hline $\begin{array}{l}\text { BATIK SUMBER } \\
\text { REJEKI }\end{array}$ & 3.000 .000 & Pinjaman bank \\
\hline $\begin{array}{l}\text { CAND's } \\
\text { COLLECTION }\end{array}$ & 500.000 & Tabungan \\
\hline $\begin{array}{l}\text { TITA } \\
\text { COLLECTION }\end{array}$ & 100.000 & Tabungan \\
\hline $\begin{array}{l}\text { IKENIA } \\
\text { HANDMADE }\end{array}$ & 500.000 & Tabungn \\
\hline LE ZUKI & 3.000 .000 & Tabungan \\
\hline $\begin{array}{l}\text { AZNAY } \\
\text { MACRAME }\end{array}$ & 4.000 .000 & Tabungan \\
\hline BATIK ARJUNA & 2.000 .000 & Pinjaman bank \\
\hline $\begin{array}{l}\text { META } \\
\text { COLLECTION }\end{array}$ & 500.000 & Pinjaman bank \\
\hline SINTA CRAFT & 400.000 & Modal sendiri \\
\hline $\begin{array}{l}\text { DIAZ's } \\
\text { CROCHET }\end{array}$ & 1.000 .000 & Modal sendiri \\
\hline $\begin{array}{l}\text { BATIK } \\
\text { SIWARAK }\end{array}$ & 750.000 & PNPM \\
\hline
\end{tabular}

Sumber; data primer,2017

Tabel 2 merupakan ikhtisar pola pembiayaan usaha UMKM Ekonomi kreatif yang berkaitan dengan modal awal. Modal awal pada usaha ekonomi kreatif sebenarnya adalah pada ketrampilan dan kreativitas untuk menghasilkan karya-karya yang unik, cantik dan menarik. Pelaku ekonomi kreatif tidak banyak membutuhkan peralatan atau perlengkapan yang bermacam-macam untuk menghasilkan produknya. Terkadang yang dibutuhkan hanya mesin jahit, gunting, kuas atau alat-alat sederhana yang tidak mahal. Maka seperti ditunjukkan pada tabel 4.5. , modal awal untuk memulai usaha ekonomi kreatif tidak besar, sehingga biasanya sumber modal awal cukup dari tabungan sendiri, tidak perlu pinjam dari Bank atau sumber keuangan yang lain. Modal awal untuk untuk memulai usaha ekonomi kreatif bisa dari hanya sebesar RP 100.000 sampai dengan Rp. 20.000.000. Berdasarkan hasil wawancara dengan informan UMKM ekonomi kreatif, rata-rata modal awal untuk memulai usaha ekonomi kreatif kurang dari Rp 500.000. Hanya UMKM produsen stiker yaitu Kingdom Label yang modal awalnya cukup besar yaitu Rp 20.000 karena peralatan produksi untuk mencetak stiker memang mahal.

Terkait dengan modal awal, beberapa para informan menyampaikan bahwa mereka baru memulai usaha maka tidak ingin menanggung risiko dengan mengambil pinjaman dari bank atau lembaga lainnya. Mereka memilih untuk menggunakan tabungan yang mereka miliki, jika masih kurang pinjam orang tua atau saudara. Berikut beberapa pernyataan dari beberapa informan yang memilih menggunakan modal sendiri untuk memulai usaha;

Cand's Collection

“Saya menggunakan tabungan saja untuk memulai usaha ini, kebetulan modal untuk usaha saya ini nggak banyak.Saya hanya butuh bahan baku seperti kain perca, manik-manik, pita, lem dan lain-lain. Peralatan untuk membuat produk kreatif saya sangat sederhana dan sudah punya.

\section{Aznay Macrame}

"Modal yang saya butuhkan untuk memulai usaha saya ini lumayan menguras tabungan saya. Tapi nggak papa daripada pinjam bank, berisiko dan masih terbebani cicilan. Saya akan berusaha modal awal ini kembali nantinya." 
Dinamika Sosial Budaya, Vol 19, No. 2, Desember 2017, pp 286-299

p-ISSN: 1410-9859\& e-ISSN: 2580-8524

http://journals.usm.ac.id/index.php/jdsb

Sinta Craft

“ Saya memilih aman, pakai tabungan saja untuk mengawali usaha. Untungnya saya tidak menggunakan bahan baku yang mahal dan banyak. Pasti nanti modal yang saya pakai untuk memulai usaha akan cepat kembali”.

Beberapa pengusaha UMKM Ekonomi Kreatif yang lain memilih mengawali usaha dengan tambahan modal dari lembaga keuangan bank, koperasi atau lainnya. Penggunaan pembiayaan modal dari sumber lain diperlukan karena modal awal yang diperlukan cukup besar dan tidak cukup jika dari tabungan atau modal sendiri. Seperti beberapa pernyataan berikut;

Kingdom Label

" Untuk memulai usaha sticker ini butuh peralatan dan mesin yang cukup mahal sehingga modal awal yang disediakan cukup besar, tabungan saya tidak cukup. Ada fasilitas dari perbankan berupa pinjaman yang cicilannya terjangkau, kenapa tidak”.

Batik Sumber Rejeki

" Pada awal saya memulai usaha ini , saya tidak punya modal sama sekali, terpaksa saya harus pinjam dari bank. Kalau saya tidak pinjam dari bank, saya tidak bisa memulai usaha. Saya memilih ambil risiko mengambil pinjaman dengan semangat pasti dapat menghasilkan pendapatan sehingga saya bisa mengembalikan pinjaman tersebut."

Kedua pernyataan di atas menunjukkan bahwa pembiayaan modal awal dengan sumber modal dari pinjaman menjadi solusi bagi pelaku usaha untuk bisa segera memulai usaha. Memang konsekuensinya adalah risiko tetapi risiko bisa dikelola dengan baik.

Modal kerja yang dibutuhkan dalam usaha ekonomi kreatif juga tidak begitu besar, bahkan ada yang sangat murah karena bahan bakunya menggunakan bahan-bahan yang tidak terpakai seperti kain perca atau limbah yang masih bisa dimanfaatkan. Modal kerja yang diperlukan berkisar dari Rp 25.000 per unit sampai Rp 250.000 per unit. Modal kerja pada UMKM Ekonomi kreatif lebih banyak untuk membeli bahan baku dan membayar tenaga kerja. Beberapa UMKM Ekonomi kreatif menggunakan modal kerja untuk ongkos kirim, transportasi, promosi dan mengikuti pameran. Besarnya modal kerja yang diperlukan oleh UMKM Ekonomi Kreatif mengikuti besarnya pesanan yang diterima. Tabel 3 menunjukkan pola pembiayan Modal Kerja UMKM Ekonomi Kreatif Kota Semarang.

Ekonomi Kreatif yang tidak menggunakan pembiayaan usaha dari sumber di luar menyatakan bahwa mereka tidak tertarik menggunakan dan lebih memilih meminjam dari saudara atau teman dengan alasan risiko nya lebih kecil dan bisa membuat kesepakatan lebih leluasa untuk kedua belah pihak. Kalau dengan pembiayaan dari pinjaman bank. Pelaku UMKM ekonomi kreatif tidak bisa menawar ke pihak bank dengan lelusasa seperti bunga maupun jangka waktu pengembalian. Kebanyakan pembiayaan modal kerja adalah dari hasil penjualan. Berdasarkan hasil wawancara ratarata pelaku UMKM menyatakan bahwa modal kerja yang digunakan sebelumnya selalu kembali dalam bentuk hasil penjualan sehingga bisa digunakan untuk modal kerja selanjutnya. Pelaku UMKM ekonomi kreatif akan menggunakan pinjaman dari bank atau lembaga keuangan lainnya jika mendapat pesanan dalam jumlah besar sehingga harus menambah jumlah modal kerja. UMKM yang berani mengambil pinjaman cenderung agresif dalam menangkap peluang. Mereka berani mengambil risiko menerima pesanan besar meskipun harus dengan pembiayaan dari bank. Menggunakan pembiayaan modal kerja dari pinjaman harus dilakukan jika ingin "naik kelas" dalam skala usaha. 
Dinamika Sosial Budaya, Vol 19, No. 2, Desember 2017, pp 286-299

p-ISSN: 1410-9859\& e-ISSN: 2580-8524

http://journals.usm.ac.id/index.php/jdsb

Tabel 3. Pola Pembiayaan Modal Kerja UMKM Ekonomi

\begin{tabular}{|c|c|c|}
\hline \multicolumn{2}{|c|}{ Kreatif Kota Semarang } & \\
\hline $\begin{array}{l}\text { UMKM } \\
\text { EKONOMI } \\
\text { KREATIF }\end{array}$ & $\begin{array}{l}\text { JUMLAH } \\
\text { MODAL } \\
\text { KERJA }\end{array}$ & $\begin{array}{l}\text { SUMBER MODAL } \\
\text { KERJA }\end{array}$ \\
\hline $\begin{array}{l}\text { KINGDOM } \\
\text { LABEL }\end{array}$ & $40.000 / 24$ unit & $\begin{array}{l}\text { Hasil penjualan, jika } \\
\text { order nya besar harus } \\
\text { pinjam dari bank }\end{array}$ \\
\hline $\begin{array}{l}\text { BATIK } \\
\text { SUMBER } \\
\text { REJEKI } \\
\end{array}$ & 80.000/unit & $\begin{array}{l}\text { Hasil penjualan jika } \\
\text { mendapat order besar } \\
\text { ditambah pinjaman }\end{array}$ \\
\hline $\begin{array}{l}\text { CAND's } \\
\text { COLLECTION }\end{array}$ & $\begin{array}{l}2.000 .000 / 60 \\
\text { unit }\end{array}$ & Hasil penjualan \\
\hline $\begin{array}{l}\text { TITA } \\
\text { COLLECTION }\end{array}$ & $40.000 / 24$ unit & Hasil penjualan \\
\hline $\begin{array}{l}\text { IKENIA } \\
\text { HANDMADE }\end{array}$ & $25.000 /$ unit & $\begin{array}{l}\text { Hasil penjualan jika } \\
\text { mendapat pesanan } \\
\text { banyak pinjam dari } \\
\text { bank }\end{array}$ \\
\hline LE ZUKI & $\begin{array}{l}\text { 3.000.000/50 } \\
\text { unit }\end{array}$ & Hasil penjualan \\
\hline $\begin{array}{l}\text { AZNAY } \\
\text { MACRAME }\end{array}$ & $70.000 /$ unit & Hasil penjualan \\
\hline $\begin{array}{l}\text { BATIK } \\
\text { ARJUNA }\end{array}$ & $1.300 .000 / \mathrm{kodi}$ & $\begin{array}{l}\text { Hasil penjualan jika } \\
\text { mendapat order besar } \\
\text { ditambah pinjaman dari } \\
\text { koperasi }\end{array}$ \\
\hline $\begin{array}{l}\text { META } \\
\text { COLLECTION }\end{array}$ & $\begin{array}{l}50.000 / \text { unit } \\
\text { bantal }\end{array}$ & $\begin{array}{l}\text { Hasil penjualan jika } \\
\text { dapat pesanan banyak } \\
\text { menggunakan pinjaman } \\
\text { bank }\end{array}$ \\
\hline $\begin{array}{l}\text { SINTA } \\
\text { COLECTION }\end{array}$ & 75.000/unit & Hasil penjualan \\
\hline $\begin{array}{l}\text { DIAZ's } \\
\text { CROCHET }\end{array}$ & 250.000/unit & Hasil penjualan \\
\hline $\begin{array}{l}\text { BATIK } \\
\text { SIWARAK }\end{array}$ & $80.000 /$ unit & $\begin{array}{l}\text { Hasil penjualan jika } \\
\text { pesanan meningkat, } \\
\text { menambah modal kerja } \\
\text { dengan pinjaman }\end{array}$ \\
\hline
\end{tabular}

Sumber; data primer

Salah satu kelemahan UMKM adalah kurangnya kesadaran untuk melakukan pencatatan keuangan dan perencanaan keuangan dalam menjalankan usahanya. Sebagian besar UMKM tidak melakukan pencatatan keuangan dan tidak memisahkan keuangan usaha dengan keuangan keluarga. Perilaku seperti ini menyebabkan UMKM sulit berkembang, karena UMKM tidak dapat megetahui berapa pendapatannya, berapa keuntungannnya dan berapa besar yang bisa diinvestasikan lagi untuk meningkatkan usahanya. Berdasarkan wawancara mendalam pada pelaku UMKM ekonomi kreatif, ditemukan perilaku yang agak berbeda di temui pada pelaku UMKM lainnya. Pelaku UMKM ekonomi kreatif yang menjadi informan sebagian besar telah melakukan pencatatan keuangan dan memisahkan keuangan usaha dengan keuangan keluarga. Dari 12 UMKM ekonomi kreatif yang menjadi informan, hanya 2 pelaku UMKM saja yang tidak melakukan pencatatan keuangan dan memisahkan keuangan usaha dengan keuangan keluarga dengan alasan tidak mempunyai waktu untuk melakukan pencatatan keuangan. Sementara 10 pelaku UMKM ekonomi kreatif lainnya memiliki kesadaran bahwa dengan melakukan pencatatan keuangan usaha dan memisahkan keuangan usaha dengan keuangan keluarga, mereka bisa mengetahui seberapa besar hasil usaha mereka, untung atau rugi dan sebagainya. Belum semua pelaku UMKM Ekonomi Kreatif tertib dan disiplin membuat pencatatan keuangan setiap hari, beberapa UMKM Ekonomi Kreatif melakukan pencatatan keuangan seminggu sekali atau beberapa hari sekali.

Pengelolaan cashflow sangat perlu diperhatikan oleh setiap pelaku usaha agar usahanya terus berlangsung. Pelaku usaha harus cermat dalam mengelola aliran penerimaan dan pengeluaran agar usaha dapat terus berjalan. Penerimaan UMKM Ekonomi Kreatif adalah hasil penjualan produk kreatifnya. Tidak seperti produk makanan , minuman atau kuliner, pembelian produk ekonomi kreatif tidak menentu. Terkadang penjualan produk ekonomi kreatif sepi, tetapi terkadang penjualan produk ekonomi kreatif sangat tinggi, misalnya pada musim liburan, musim pernikahan dan lain-lain. Dengan demikian kondisi yang terjadi pada UMKM Ekonomi Kreatif adalah penjualan tidak terjadi setiap hari, tetapi produksi harus setiap hari. Berdasarkan wawancara modal kerja yang digunakan biasanya selalu kembali dan bisa digunakan lagi untuk produksi selanjutnya, hanya tidak selalu sekaligus karena penjualan produk 
Dinamika Sosial Budaya, Vol 19, No. 2, Desember 2017, pp 286-299

p-ISSN: 1410-9859\& e-ISSN: 2580-8524

http://journals.usm.ac.id/index.php/jdsb

ekonomi kreatif tidak menentu setiap harinya. Pengelolaan cashflow menjadi kunci keberlangsungan usaha mereka.

Pengelolaan cash flow yang banyak diterapkan oleh pelaku UMKM ekonomi kreatif adalah dengan meminimalkan piutang, memaksimalkan penjualan, meminimalkan piutang dan juga dengan efisiensi biaya produksi. Yang tersulit adalah meminimalkan piutang karena berhubungan dengan pihak lain, seperti perusahaan besar atau pemerintah. Beberapa UMKM ekonomi kreatif menjelaskan bahwa jika mereka mendapat pesanan dari pemerintah, tempo pembayarannya akan lama sekali. Hal ini cukup membuat UMKM ekonomi kreatif kewalahan dalam mengatur cash flownya.

Berdasarkan fenomena yang telah diamati pada pelaku UMKM Ekonomi Kreatif ditemukan bahwa pola pembiayaan usaha UMKM Ekonomi Kreatif baik untuk modal awal maupun modal kerja oleh UMKM Ekonomi Kreatif dapat dikelompokkan menjadi dua. Kelompok yang pertama, adalah kelompok UMKM yang lebih banyak mengandalkan modal sendiri, baik untuk modal awal maupun modal kerja dan kelompok kedua adalah kelompok UMKM yang berani melakukan pembiayaan dengan sumber modal dari bank atau lembaga keuangan lainnya. Para pelaku UMKM Ekonomi kreatif yang berani menggunakan pembiayaan dari sumber lain seperti bank dan koperasi adalah pelaku usaha yang berani mengambil risiko dan agresif untuk meningkatkan skala usahanya. Pembiayaan dari sumber lain harus dilakukan ketika UMKM Ekonomi Kreatif memperoleh pesanan dalam jumlah besar sehingga harus menambah belanja bahan baku dan menambah jumlah tenaga kerja. Kelompok UMKM Ekonomi Kreatif yang berani menggunakan pembiayaan modal awal maupun modal kerja dari sumber lain paling banyak mengakses pinjaman dari perbankan, diantaranya Bank Mandiri, BNI, BRI. Faktor pendukung yang mendorong pelaku UMKM Ekonomi Kreatif memilih sumber pembiayaan dari bank-bank tersebut adalah lokasi yang dekat, persyaratan mudah, bunga ringan, tanpa agunan dan sudah dikenal baik oleh bank yang bersangkutan. Beberapa informan mengatakan bahwa mereka mengandalkan pembiayaan bank untuk membiayai order-order yang besar. Beberapa sudah sering pinjam di bank dan akhirnya terjalin kepercayaan bank terhadap pelaku UMKM Ekonomi Kreatif. Mereka juga mendapatkan pelayanan yang memuaskan dalam proses peminjaman sampai dengan pelunasan pinjaman. Sementara kelompok pelaku UMKM Ekonomi Kreatif yang tidak menggunakan pembiayaan usaha dari sumber di luar menyatakan bahwa mereka tidak tertarik menggunakan dan lebih memilih meminjam dari saudara atau teman dengan alasan risiko nya lebih kecil dan bisa membuat kesepakatan lebih leluasa untuk kedua belah pihak. Kalau dengan pembiayaan dari pinjaman bank. Pelaku UMKM ekonomi kreatif tidak bisa menawar ke pihak bank dengan lelusasa seperti bunga maupun jangka waktu pengembalian.

Pembiayaan modal kerja dari perbankan telah menjadi alternatif bagi pelaku UMKM Ekonomi Kreatif karena saat ini perbankan juga banyak menfasilitasi UMKM yang memiliki kinerja usaha yang terus membaik. Jumlah pinjaman pelaku UMKM Ekonomi kreatif sebagai pembiayaan modal kerja berkisar antara Rp 1 - 10 juta. Beberapa informan tidak bersedia menyampaikan berapa besar pinjamannya di Bank dengan alasan privacy. Besarnya pinjaman para pelaku UMKM Ekonomi Kreatif cenderung tidak dalam jumlah besar dan jangka waktu pengembalian cukup pendek. Para informan menyatakan mereka tidak ingin banyak terbebani dengan pinjaman bank. Konsekuensi yang 
Dinamika Sosial Budaya, Vol 19, No. 2, Desember 2017, pp 286-299

p-ISSN: 1410-9859\& e-ISSN: 2580-8524

http://journals.usm.ac.id/index.php/jdsb

muncul dari dilakukannya pinjaman di bank adalah bunga dan cicilan per bulan dalam jangka waktu tertentu. Para pelaku UMKM Ekonomi kreatif harus pintar dalam mengatur keuangan agar dapat memenuhi kewajiban kepada bank. Beberapa strategi yang banyak diterapkan oleh para pelaku UMKM agar dapat memenuhi kewajiban membayar cicilan pinjaman di Bank terlihat di Tabel 4.11. Para pelaku UMKM Ekonomi Kreatif megatur keuangan agar membayar cicilan dengan cara; 1) membayar cicilan secara disiplin, tepat waktu dan jangan sampai menunggak; 2) ketika ada keuntungan yang lebih besar, mempercepat pembayaran cicilan agar cepat lunas; 3) menyisihkan keuntungan secara rutin per hari/ minggu untuk cicilan pinjaman secara disiplin; 4) jangan menambah pinjaman jika pinjaman belum lunas. Cara-cara tersebut cukup efektiv dalam menjaga kemampuan untuk memenuhi kewajiban kepada bank sehingga pihak bank memberi kepercayaan yang semakin baik kepada para pelaku UMKM Ekonomi Kreatif.

Kinerja usaha para pelaku UMKM yang menjadi informan dalam penelitian ini cukup memuaskan. Berdasarkan wawancara mendalam dan observasi langsung ditempat usaha para pelaku UMKM Ekonomi Kreatif terbukti bahwa kinerja usaha UMKM Ekonomi Kreatif cukup bagus dimana terlihat dari indiktor; 1) meningkatnya produksi; 2) meluasnya jangkauan pemasaran; 3) omzet yang terus meningkat dari waktu ke waktu; 4) kepemilikan asset berkembang; dan dirasakan skala usaha yang dijalankan semakin berkembang dan semakin besar.

Pelaku UMKM Ekonomi Kreatif yang agresif akan berani mengambil risiko dalam menjalankan usahanya termasuk dalam hal pembiayaan. Berdasarkan hasil wawancara mendalam diperoleh informasi bahwa pelaku UMKM Ekonomi Kreatif yang berani mengambil risiko dapat berkembang lebih cepat dibanding pelaku Ekonomi Kreatif yang tidak mau mengambil risiko. Berani mengambil risiko dalam hal ini, para pelaku UMKM ekonomi kreatif yang agresif berani mencoba menghasilkan produk baru, berani menerima pesanan dari customer baru dengan jumlah besar, berani mencoba menjangkau wilayah pemasaran yang baru dan berani menambah peralatan atau perlengkapan produksi yang baru. Upaya-upaya tersebut dapat dilakukan dengan menggunakan pembiayaan dari sumber lain seperti perbankan, koperasi dan lainlain. Pembiayaan usaha yang tidak hanya mengandalkan modal sendiri, namaun juga distimulasi dengan dana dari luar ternyata dirasakan berdampak positif bagi para pelaku UMKM Ekonomi Kreatif. Pernyataan mereka dalam wawancara mendalam terkait dengan dampak pembiayaan usaha dengan modal dari adalah ; 1) pembiayaan modal dari bank sangat membantu untuk mempercepat pengembangan usaha; 2) pembiayaan modal dari sumber lain sangat membantu memperlancar dan membesarkan usaha; 3) pembiayaan modal dari sumber lain membantu meningkatkan produksi dan membantu dalam emanfaatkan peluang ketika ada order besar.

\section{Analisis Informasi dari Dinas Koperasi dan UMKM Kota Semarang}

Dinas Koperasi dan UMKM Kota Semarang adalah pihak yang bertugas untuk membina dan menfasilitasi UMKM di Kota Semarang. Peneliti melakukan wawancara secara mendalam dengan 2 orang penting yang tugasnya sangat strategis dalam pengembangan umkm di Kota Semarang, yaitu Ibu Litani Kepala Dinas Koperasi dan UMKM Kota Semarang dan Ibu Maria yang merupakan kepala bidang pengembangan UMKM. Menurut Ibu Litani UMKM Ekonomi Kreatif Di Kota Semarang telah berkembang dengan baik bahkan sudah ada produk ekonomi kreatif yang diangkat sebagai produk 
Dinamika Sosial Budaya, Vol 19, No. 2, Desember 2017, pp 286-299

p-ISSN: 1410-9859\& e-ISSN: 2580-8524

http://journals.usm.ac.id/index.php/jdsb

OVOP (One Village One Product). Produk ekonomi kreatif Kota Semarang kebanyakan muncul dari ibuibu yang mengembangkan hobinya menjadi usaha yang menghasilkan pendapatan seperti rajutan, kreasi dari limbah kemasan plastic, sulam pita dan berbagai produk kreatif lainnya. Sulam pita diangkat menjadi produk unggulan Kota Semarang dan dinyatakan sebagai produk OVOP nya Kota Semarang.

Dinas Koperasi dan UMKM Kota Semarang telah memberikan berbagai support dan fasilitas untuk mengembangkan UMKM ekonomi Kreatif di Kota Semarang. Dukungan dan fasilitas yang diberikan kepada UMKM ekonomi kreatif mencakup bantuan modal, pelatihan, fasilitas pemasaran dan promosi. Bantuan modal yang diberikan oleh Dinas Koperasi dan UMKM berupa pinjaman lunak yang diberi nama kredit Wibawa. Kredit Wibawa disalurkan melalui dua skema yaitu tanpa agunan dan pakai agunan. Nasabah yang tidak memakai agunan akan mendapat pinjaman maksimal Rp 5 juta, sedangkan jika pakai agunan pinjaman maksimal Rp 50 juta.

Kredit Wibawa ini diluncurkan pada Februari 2017 oleh Pemerintah Kota Semarang. Kredit Wibawa ini adalah pinjaman dengan bunga rendah hanya tiga persen/tahun.Pengajuan Kredit Wibawa juga dimudahkan dengan layanan "call centre" (024) 3584-086 yang akan dipandu pengajuannya sehingga tidak perlu kerepotan datang ke kantor.Untuk meningkatkan penyaluran kredit tersebut, Dinas Koperasi dan UMKM melakukan promosi dengan menyebar brosur kredit Wibawa di wilayah-wilayah yang sekiranya banyak UMK yang membutuhkan tambahan modal. Seminggu 2 kali , brosur mengenai kredit wibawa dibawa ke pasarpasar sambil mensosialisasikan kredit wibawa tersebut. untuk syarat pengajuan kredit melalui Dinas Koperasi dan UMKM Kota Semarang.
Setelah dilakukan verifikasi, kemudian nasabah mengurus permohonan di PD BPR Bank Pasar. Setelah dilakukan BI checking dan data tidak muncul berarti kredit wibawa bisa diberikan. Penerima kredit wibawa harus nasabah yang benarbenar bertanggung jawab dengan pengembalian kreditnya.

Pihak pemerintah kota Semarang dalam hal ini adalah Dinas Koperasi dan UMKM telah berupaya membantu UMKM Ekonomi Kreatif untuk mengatasi permasalahan dalam hal pembiayaan usaha dengan skema kredit yang sangat ringan. Dinas Koperasi dan UMKM Kota Semarang juga memberikan pelatihan-pelatihan yang berkaitan dengan pengelolaan keuangan dan pembiayaan bagi para pelaku UMKM.

\section{Kesimpulan}

Penelitian mengenai pola pembiayaan modal kerja pada pelaku UMKM Ekonomi Kreatif di Kota Semarang dengan pendekatan fenomenologis menemukan kesimpulan menarik sebagai berikut : terdapat dua kelompok dalam pola pembiayaan modal kerja yaitu, 1) kelompok UMKM Ekonomi Kreatif yang tidak berani mengambil risiko, bermain aman dengan modal yang ada dan tidak berani menggunakan sumber pembiayaan dari perbankan atau lainnya ; dan 2) kelompok UMKM Ekonomi Kreatif yang agresif, berani mengambil risiko, berani mencoba memanfaatkan peluang baru, berani menggunakan pembiayaan dari sumber lain untuk lebih mengembangkan usahanya.Pelaku UMKM Ekonomi kreatif yang agresif dan memilih menggunakan pembiayaan modal kerja dalam usahanya berusaha mengatur cash flow sebaik mungkin dengan memaksimalkan penjualan, meminimalkan piutang dan efisiensi biaya. 
Dinamika Sosial Budaya, Vol 19, No. 2, Desember 2017, pp 286-299

p-ISSN: 1410-9859\& e-ISSN: 2580-8524

http://journals.usm.ac.id/index.php/jdsb

Faktor pendukung untuk menggunakan pembiayaan usaha dengan sumber modal dari perbankan atau lembaga keuangan lainnya adalah prosedur pengajuan pinjaman yang mudah, bunga ringan, tidak perlu dengan agunan, pihak UMKM sudah mendapat kepercayaaan dari bank atau lembaga keuangan lainnya. Faktor penghambat untuk menggunakan pembaiyaan usaha dengan sumber modal dri perbankan atau lembaga keuangan lainnya adalah risiko yang muncul dari pinjaman tersebut.

Kekhawatiran UMKM ekonomi kreatif ke depan tidak bisa memenuhi kewajiban dengan baik menjadi faktor penghambat untuk menggunakan pembiayaan usaha dari perbankan atau lembaga keuangan yang lain. Pelaku ekonomi kreatif yang menggunakan pembiayaan modal kerja dengan pinjaman perbankan mengatur pembayaran cicilan pinjaman ke perbankan dengan disiplin memenuhi kewajiban, tidak menambah pinjaman sebelum lunas, dan mempercepat cicilan jika ada keuntungan berlebih. Pelaku UMKM Ekonomi Kreatif telah mendapatkan fasilitas dan dukungan dari Pemerintah Kota Semarang dalam aspek pembiayaan usaha berupa kredit tanpa agunan dengan bunga pinjaman yang sangat rendah dan disertai dengan pendampingan dan pelatihan dalam hal pengelolaan keuangan usaha.

Pelaku UMKM ekonomi kreatif yang agresif merasakan dampak positif dari penggunaan pembiayaan modal kerja dalam menjalankan usahanya. Dampak yang dirasakan adalah: produksi meningkat; pemasaran meningkat; omzet meingkat, keuntungan meningkat dan mampu meingkatkan skala usaha.

\section{Saran}

Penelitian selanjutnya dengan topik pola pembiayaan usaha UMKM sebaiknya memperdalam masalah pola pembiayaan usaha pada UMKM dengan metode analisis data yang lain. Hasil penelitian ini perlu dimanfaatkan sebagai dasar untuk memberikan pendampingan kepada UMKM dalam pola pembiayaan usaha agar UMKM mampu mencapai kinerja usaha yang optimal.

\section{Daftar pustaka}

Astriningsih, dkk.,Analisis Potensi Sosial Ekonomi dan Budaya Masyarakat di Wilayah Kota Semarang Dalam Pengembangan Industri Kreatif., Riptek, Vol.4, No.I1, Tahun 2010. (PDF Download Available).[accessed Sep 3, 2017.

, 2008. "Pengembangan Ekonomi Kreatif Indonesia 2025". Departemen Perdagangan Republik Indonesia. Depdag RI, 2008.

2008. "Rencana Pengembangan Ekonomi Kreatif 2009-2025”. Departemen Perdagangan Republik Indonesia. Depdag RI, 2008.

Claire, Lynnette. 2009. "Growing a Creative economy-One Experiment". University of Puget Sound.

Creswell, John W. 1998, Qualitative Inquiry and Research Design, Choosing. Among Five Traditions. California: Sage Publication

Denzin dan Lincoln 1994, Hand Book of Qualitative Research, Sage. Publication. Thousan oaks, London.

Foord, J. 2008. Strategies for creative industries: an international review. Creative Industrie Journal, Volume 1 Number 2 (C) 2008 Intellect Ltd Article. English language. doi:10.1386/cij.1.2.91/1

Guba, Egon G., and Yvonna S. Lincoln. 1994. "Competing Paradigms in Qualitative Research," dalam Norman

K. Denzim and Yvonna S. Lincoln , (eds). Handbook of Qualitative Research. California: Sage Publications 
Dinamika Sosial Budaya, Vol 19, No. 2, Desember 2017, pp 286-299

p-ISSN: 1410-9859\& e-ISSN: 2580-8524

http://journals.usm.ac.id/index.php/jdsb

Herdiansyah, Haris. 2009. Metodologi Penelitian Kualitatif untuk Ilmu Sosial. Jakarta:Salemba, Humanika.

Kuncoro, Mudrajad.2009. Metode Riset Untuk Bisnis \& Ekonomi. Penerbit Erlangga. Jakarta.

Moleong., J.Lexy 2005. metodologi penelitian kualitatif, Bandung: Remaja. Rosdakarya

Pangestu, ME. 2008. "Pengembangan Industri Kreatif Menuju Visi Ekonomi Kreatif Indonesia 2025". Departemen Perdagangan Republik Indonesia.

UNTACD, 2008, Creative Economy Report 2008. Geneva

Zhang, Hongman, Wang, Jing, and Liu, D. 2011. Experiences of Creative Industries Development in Developed Countries and Enlightenments. Asian Social Science Journal, Vol. 7 No. 8 
Dinamika Sosial Budaya, Vol 19, No. 2, Desember 2017, pp 286-299

p-ISSN: 1410-9859\& e-ISSN: 2580-8524

http://journals.usm.ac.id/index.php/jdsb 